\title{
Livros Recebidos
}

\section{Editora Paulinas}

KESSLER, Rainer, História social do Antigo Israel, São Paulo, Paulinas, 2009, 297p., ISBN: 978-85-356-2529-5.

MARSILI, Salvatore, Sinais do Ministério de Cristo - Teologia Litúrgica dos sacramentos, espiritualidade e ano litúrgico, São Paulo, Paulinas, 2010, 709p., ISBN: 978-85-356-2553-0.

OTTAVIANI, Edélcio, TÓTORA, Silvana (orgs.), Educação e extensão universitária - foco Vestibular: um experimento da diferença, São Paulo, Paulinas/EDUC, 2010, 231p., ISBN: 978-85-356-2555-4.

MURAD, Afonso, GOMES, Paulo Roberto, RIBEIRO, Súsie, A casa da teologia - Introdução ecumênica à ciência da fé, São Paulo, Paulinas/Sinodal, 2010, 246p., ISBN: 978-85-356-2578-3.

PASSOS, João Décio, Teologia e outros saberes - Uma introdução ao pensamento teológico, São Paulo, Paulinas, 2010, 203p., ISBN: 97885-356-2589-9.

SOARES, Afonso M.L., PASSOS, João Décio, Teologia e direito - O mandamento do amor e a meta da justiça, São Paulo, Paulinas, 2010, 244p., ISBN: 978-85-356-2590-5.

NOGUEIRA, Paulo augusto de Souza, MACHADO, Jonas (orgs.), Morte e ressurreição de Jesus - Reconstrução e hermenêutica. Um debate com John Dominc Crossan, São Paulo, Paulinas, 2009, 167p., ISBN: 978-85-356-2510-3. 
MALZONI, Cláudio Vianney, 25 lições de iniciação ao grego do Novo Testamento, São Paulo, Paulinas, 2010, 156p., ISBN: 978-85-356-2551-6.

CALVANI, Carlos Eduardo, Teologia da Arte - Espiritualidade, Igreja e Cultura a partir de Paul Tillich, São Paulo, Paulinas/Fonte, 2010, 407p., ISBN: 978-85-86671-97-5.

LESBAUPIN, Ivo, PINHEIRO, Josè Ernanne (orgs.), Democracia, Igreja e cidadania - Desafios atuais, São Paulo, Paulinas, 2010, 237p., ISBN: 978-85-356-2607-0.

HAUGHT, John F., Cristianismo e ciência - Para uma teologia da natureza, São Paulo, Paulinas, 2010, 292p., ISBN: 978-85-356-2566-0.

CATÃO, Francisco, Teologia espiritual, São Paulo, Paulinas/Siquem, 2009, 196p., ISBN: 978-85-356-2538-7.

SELF, David, Religiões do Mundo, São Paulo, Paulinas, 2010, 40p., ISBN: 978-85-356-2480-9.

\section{Editora Paulus}

SOUSA, Mauro Araújo, Nietzsche: Viver intensamente, tornar-se o que se é, São Paulo, Paulus, 2009, 126p., ISBN: 978-85-349-3154-0.

CINTRA, Benedito E. Leite, Pensar com Emanuel Levinas, São Paulo, Paulus, 2009, 118p., ISBN: 978-85-349-3117-5.

SILVA, Maria Freire da, Trindade, Criação e ecologia, São Paulo, Paulus, 2009, 287p., ISBN: 978-85-349-3115-1.

MUNSTERMAN, Hemdro, Maria corredentora?, São Paulo, Paulus, 2009, 115p., ISBN: 978-85-349-3011-6.

TEIXEIRA, João de Fernandes, Inteligência artificial, São Paulo, Paulus, 2009, 68p., ISBN: 978-85-349-3019-2

OLIVEIRA, Luizir de, Sêneca, uma vida dedicada à filosofia, São Paulo, Paulus, 2010, 144p., ISBN: 978-85-349-3125-0.

KAHN, Charles H., A arte e o pensamento de Heráclito: Uma edição dos fragmentos com tradução e comentário, São Paulo, Paulus, 2009, 493p., ISBN: 978-85-349-2938-7.

MANZATTO, Antonio, PASSOS, João Décio, VILAC, Sylvia, De esperança em esperança, São Paulo, Paulus, 2009, 152p., ISBN: 978-85-3493020-8.

AMBRÓSIO, Santo, Examerão: Os seis dias da criação, São Paulo, Paulus, 2009, 278p., ISBN: 978-85-349-3102-1.

\section{Isidoro Mazzarolo}

MAZZAROLO, Isidoro, As três cartas de São João: Exegese e comentário, Rio de Janeiro, 2010, 138p., ISBN: 978-85-89-383134. 


\section{Editora PUC-Rio}

FERNANDES, Leonardo Agostini, A Bíblia e a sua mensagem: Introdução à leitura e ao estudo da Bíblia, Rio de Janeiro, PUC-Rio, 2010, 223p., ISBN: 978-85-87926-91-3.

\section{Quártica Editora}

BOUZON, Emanuel, Ensaios sobre o direito cuneiforme, Rio de Janeiro, Quártica, 2010, 143p., ISBN: 978-85-7801-154-3.

\section{Editora Vozes}

TEIXEIRA, Faustino (org.), Sociedade da Religião: Enfoques teóricos, Petrópolis, Vozes, 2010, 270p., ISBN: 978-85-326-2929-6.

TEIXEIRA, Faustino, MENEZES, Renata (orgs.), Catolicismo Plural: Dinâmicas contemporâneas, Petrópolis, Vozes, 2009, 212p., ISBN: 978-85-326-3882-3. 